\title{
Lipid Rafts and Anti-Glycolipid Antibodies
}

\author{
脂質ラフトと抗糖脂質抗体
}

\author{
Kasahara, Kohji \\ Laboratory of Biomembrane, Tokyo Metropolitan Institute of Medical Science, Setagaya-ku, Tokyo 156-8506, Japan \\ FAX: +81-3-5316-3336, E-mail: kasahara-kj@igakuken.or.jp
}

(Received on April 1, 2014, accepted on April 21, 2014)

Key Words: lipid rafts, glycosphingolipid, ganglioside, antibody, signal transduction

\begin{abstract}
Lipid rafts are dynamic assemblies of glycosphingolipids, cholesterol, and proteins that can be stabilized into platforms involved in the regulation of signal transduction. Compositional and functional heterogeneities exist in lipid rafts. Anti-glycosphingolipid monoclonal antibodies can isolate compositionally specific lipid rafts including signaling molecules from various cells or tissues. Treatment of intact cells with anti-glycosphingolipid monoclonal antibodies can induce transmembrane signaling via specific lipid rafts. Therefore, anti-glycosphingolipid monoclonal antibodies are useful tools for the analysis of heterogeneity in raft signaling. Guillain-Barré and Fisher syndromes are autoimmune neuropathies with the clinical symptom of peripheral nerve dysfunction. Lipid raft function might be impaired by the patient's anti-ganglioside antibody.
\end{abstract}

\section{A. Introduction}

Lipid rafts are dynamic assemblies of glycosphingolipids, sphingomyelin, cholesterol, and proteins that can be stabilized into platforms involved in the regulation of a number of vital cellular processes (1). Low-density, detergent-resistant membrane fractions can be isolated from cells by sucrose density gradient centrifugation. These membrane fractions are rich in glycosphingolipids, sphingomyelin, cholesterol, and a variety of signaling molecules. These observations indicate the presence of lipid rafts in cells and their involvement in signal transduction.

Glycosphingolipids and sphingomyelin are relatively rich in saturated fatty acyl chains, which allow tight packing and confer the characteristic of a high melting temperature. On the other hand, phospholipids are relatively rich in cis-unsaturated fatty acyl chains, which prevent tight packing and confer the characteristic of a low melting temperature. Furthermore, both sides of the plasma membrane in lipid rafts have an elevated content of cholesterol, which leads to the formation of a liquid-ordered domain with sphingolipids that exhibits less fluidity than the surrounding phospholipid bilayer. Consistent with this idea, dipalmitoylphosphatidylcholine is present in the raft fraction of rat cerebellar granule

\section{要 約}

脂質ラフトはスフィンゴ糖脂質、コレステロールとタン パク質のダイナミックな集合体であり、安定化することでシ グナル伝達制御にかかわる中継点として働く。脂質ラフトに は質的および機能的な不均一性が存在することが知られてい る。抗スフィンゴ糖脂質モノクローナル抗体はシグナル伝達 分子を含む質的に特異的な脂質ラフトをさまざまな細胞や組 織から単離することができる。無傷細胞を抗スフィンゴ糖脂 質モノクローナル抗体で処理すると、特異的な脂質ラフトを 介したシグナル伝達を惹起することができる。よって抗ス フィンゴ糖脂質モノクローナル抗体は、ラフトシグナルの不 均一性を解析するうえで有用な道具である。ギランバレー症 候群やフィッシャー症候群は、末梢神経障害を臨床症状とす る自己免疫性神経疾患である。患者の抗ガングリオシド抗体 は、脂質ラフトの機能を障害しているかもしれない。

\section{A. 序論}

脂質ラフトはスフィンゴ糖脂質、スフィンゴミエリン、 コレステロールとタンパク質のダイナミックな集合体であ り、安定化することで細胞の生命維持に必要な数々の過程の 制御にかかわる中継点として働いている(1)。ショ糖密度勾 配遠心法によって低密度界面活性剂耐性膜画分を細胞から単 離することができる。この膜画分はスフィンゴ糖脂質、ス フィンゴミエリン、コレステロールとさまざまなシグナル伝 達分子に富んでいる。これらのことは、細胞に脂質ラフトが 存在し、シグナル伝達にかかわっていることを示している。

スフィンゴ糖脂質とスフィンゴミエリンは相対的に飽和 脂肪酸鎖に富み、固くパックすることができ相転移温度が高 い性質を持つ。一方、リン脂質は相対的にシス二重結合不飽 和脂肪酸鎖に富み、固くパックすることができず相転移温度 が低い性質を持つ。さらに脂質ラフトにおいて形質膜の両側 はコレステロール濃度が高く、スフィンゴ脂質とともに秩序 液晶相領域を形成し、そこは周囲のリン脂質二重層より流動 性が低い。ラット小脳顆粒細胞の脂質ラフト画分においてジ パルミトイルフォスファチジルコリンが存在することは、そ 
cells (2). Phosphatidylglucoside (PtdGlc) with saturated fatty acyl chains is also present in the raft fraction of human leukemia HL-60 cells (3). Hydrogen bonding among the carbohydrate moieties in glycosphingolipids is also considered to contribute to the formation of lipid rafts.

Src-family tyrosine kinases and trimeric G protein $\alpha$ subunits are modified by saturated-chain lipids: palmitoylation and myristoylation, which are likely to be inserted preferentially into lipid rafts. The Csk-binding protein ( $\mathrm{Cbp} / \mathrm{PAG})$ and the linker for activation of $\mathrm{T}$ cells (LAT) are transmembrane adaptor proteins in lipid rafts, which undergo palmitoylation on two residues (4, 5). Recent studies have shown that the modification and affinity of these proteins can be dynamically regulated depending on the physiological stimulus. Several proteins are therefore found only transiently associated with lipid rafts, by either entering or leaving these compartments in response to extracellular or intracellular events, such as ligand binding or phosphorylation. The specific and dynamic localization of various signaling molecules is postulated to support signal integration. For example, efficient T-cell activation requires one signal from a T-cell receptor and a second signal from the costimulatory molecules. The costimulation leads to the coalescence of lipid rafts to the site of contact between a $T$ cell and an antigen-presenting cell. The accumulation of src-family tyrosine kinases and their substrate LAT adaptor protein, and the exclusion of tyrosine phosphatase CD45 allow stable tyrosine phosphorylation of several substrates, leading to T-cell activation (6). One of the raft coalescence mechanisms involves an interaction between galectin-1 and ganglioside GM1.

Lipid rafts are also involved in membrame trafficking: Golgi trafficking to the cell surface and glycosphingolipid-mediated endocytosis. The transport machinery in the trans-Golgi network of epithelial cells sorts lipids and proteins into common carrier vesicles for targeted delivery to the apical or basolateral surface. Forssman glycolipids, together with cholesterol, generate a hydrogen-bonded network, and the interaction between Forssman glycolipids and galectin-9 generates foci for raft coalescence in the trans-Golgi network to facilitate apical transport carrier formation in epithelial MDCK cells (7). Furthermore, galectin-9 is a critical factor for apical membrane biogenesis. When galectin-9 is knocked down by RNAi, MDCK cells fail to establish apicalbasolateral polarity. Similarly, the interaction between sulfatide and galectin-4 is involved in the apical sorting in epithelial HT29 cells (8). The yeast raft lipids, which are three classes of sphingolipids (inositolphosphoceramide, mannosyl-inositolphosphoceramide and mannosyl-diinositolphosphoceramide) and the cholesterol homologue ergosterol, were also shown to regulate the delivery of detergent-resistant cargos to the plasma membrane. Shiga toxin
の考えと一致している $(2)$ 。飽和脂肪酸鎖を持つフォスファ チジルグルコシド (PtdGlc) もヒト白血病 HL-60細胞のラフ 卜画分に存在している $(3)$ 。スフィンゴ糖脂質の糖鎖部分同 士の水素結合も脂質ラフトの形成に貢献していると考えられ ている。

$\mathrm{Src}$ ファミリーチロシンキナーゼや 3 量体 $\mathrm{G}$ タンパク質 $\alpha$ サブユニットはパルミトイル化やミリストイル化といった 飽和脂肪酸鎖で修飾されていて、脂質ラフトに優先的に挿入 されやすい。Csk結合タンパク質 $\mathrm{Cbp} / \mathrm{PAG}$ と $\mathrm{T}$ 細胞活性化リ ンカーLATは2 カ所のアミノ酸残基がパルミトイル化されて 脂質ラフトに局在する膜貫通型アダプタータンパク質である $(4,5)$ 。最近の研究からその修飾と親和性は、生理的な刺激 に依存してダイナミックに制御されている。それゆえいくつ かのタンパク質は脂質ラフトとの結合はほんの一時的で、リ ガンドの結合やリン酸化といった細胞外または細胞内の反応 によって入ったり出たりしている。この特異的でダイナミッ クなさまざまなシグナル伝達分子の局在が、シグナル調整を 支える前提となっている。例えば、 $\mathrm{T}$ 細胞が効果的に活性化 するためには、 $\mathrm{T}$ 細胞受容体からの一つの刺激と補助刺激分 子からの二つ目の刺激が必要である。補助刺激は $\mathrm{T}$ 細胞と抗 原提示細胞の接着部位に脂質ラフトを集め合体させる。 Src ファミリーチロシンキナーゼとその基質であるLATアダプ タータンパク質が集まり、チロシン脱リン酸化酵素 CD45が 排除されることにより、いくつかの基質タンパク質の安定し たチロシンリン酸化が可能となり、 $\mathrm{T}$ 細胞が活性化する $(6)$ 。 ラフト合体の一つの機構は、ガレクチン -1 とガングリオシド GM1 との相互作用によっている。

脂質ラフトは、ゴルジ体から細胞表面への輸送やスフィ ンゴ糖脂質を介したエンドサイトーシスなどの膜輸送にもか かわっている。上皮細胞においてトランスゴルジネットワー クから脂質とタンパク質を共通の運搬小胞に載せアピカルま たはバソラテラル側の表面に運ぶ。フォルスマン糖脂質は水 素結合したコレステロールとともに、ガレクチン-9 と相互作 用することが、MDCK上皮細胞のトランスゴルジネットワー クからアピカル輸送運搬者としてのラフトの合体の中心とし て働いている(7)。さらにガレクチン-9はアピカル膜領域の 形成においても重要である。ガレクチン-9をRNAi法でノッ クダウンすると、MDCK細胞におけるアピカル、バソラテ ラル極性の形成ができなくなる。同じようにHT29上皮細胞 のアピカル輸送においてスルファチドとガレクチン-4の相互 作用がかかわっている $(8)$ 。3種類のスフィンゴ脂質である イノシトールフォスフォセラミド、マンノシルイノシトール フォスフォセラミド、マンノシルジイノシトールフォスフォ 
binds glycosphingolipids as surface receptors and is internalized by a glycosphingolipid-mediated clustering process. Shiga toxin B subunits are able to bind as a pentamer to glycosphingolipid Gb3. The Shiga toxin binding takes place in the liquid-ordered phase, which induces the segregation of Gb3 into high-density clusters and the formation of narrow tubular invaginations via a machinery that leads to the release from the plasma membrane into the cytoplasm (1).

The presence of lipid rafts in vivo is supported by several lines of evidence, including the results of fluorescence resonance energy transfer analysis, fluorescence correlation spectroscopy, stimulated emission depletion microscopy, and chemical crosslinking (1). A single-molecule imaging microscopy technique is a powerful tool for the study of raft signaling in living cell plasma membranes. Single-molecule imaging has revealed that molecules are frequently, but transiently, recruited to lipid rafts with the aid of protein-protein, protein-lipid, and lipid-lipid interactions. Individual signaling molecules within lipid rafts are activated only for a short period of time. The transient nature of molecular interactions in lipid rafts generates digital-like signal transduction in the cell membrane (9).

\section{B. Anti-Glycolipid Antibodies}

Membrane glycolipids represent tumor-associated antigens. Many glycolipids are over-expressed and altered in tumors compared with normal tissue. Antibodies that recognize tumor glycolipids are strong activators of complements and strong mediators of antibody-dependent cellular cytotoxicity. Therefore, glycolipid markers can be useful targets for the diagnosis and therapy of human cancer (10).

The crypticity of glycolipids is a difficult problem to overcome when these antigens are pursued as a target of cancer immunotherapy. A monoclonal antibody M2590, previously established by immunization of mice with syngenic melanoma B16 cells, is directed against ganglioside GM3. The reactivity of the antibody M2590 depends on the density of GM3 exposed at the B16 cell surface (11). There is a threshold density of GM3 at which the antibody recognizes it in an all-or-none manner. The reactivity of the antibody M2590 also depends on the density of human glioma KG-1C cells (12). Cryptic GM3 does exist in the outer cell membrane, and the crypticity of GM3 is reversible. KG-1C glioma cells express GM3 as their sole glycolipid component, so there should be no steric hindrance from other glycolipid molecules. Ganglioside GM1 in living neuronal membranes is masked from binding to the anti-GM1 monoclonal antibody DG1 by an interaction with ganglioside GD1a, which shields a critical domain of the oligosaccharide head group involved in antibody binding (13). The
セラミドとコレステロールに相当するエルゴステロールから 成る酵母のラフト脂質は、界面活性剂耐性の形質膜への輸送 貨物を制御していることが示されている。

志賀毒素は表面受容体としてスフィンゴ糖脂質に結合 し、スフィンゴ糖脂質を介するクラスター化の過程により取 り达まれる。志賀毒素Bサブユニットはペンタマーでスフィ ンゴ糖脂質 $\mathrm{Gb} 3$ に結合する。この志賀毒素の結合が秩序液晶 相で起こり、Gb3 を高密度のクラスターとして分離し、狭い 管状の陥没を形成し、形質膜から細胞質へ放出される装置と して使われる(1)。

脂質ラフトがin vivoでも存在することは、蛍光共鳴エネ ルギー移動、蛍光相関分光法、誘導放射抑制顕微鏡や化学架 橋法の結果を含むいくつかの証拠から支持されている (1)。 一分子イメージング顕微鏡技術は、生きた細胞膜上でのラフ トシグナルの研究において強力な道具である。一分子イメー ジングは、タンパク質ータンパク質相互作用、タンパク質-脂 質相互作用、脂質一脂質相互作用によって分子が脂質ラフト に頻繁にしかし一過性に移行することを示した。それぞれの シグナル伝達分子は脂質ラフト内で、ほんの短い時間のみ活 性化される。脂質ラフトにおいて分子が一過性に相互作用を することから、細胞膜におけるシグナル伝達はデジタル方式 であると考えられている(9)。

\section{B. 抗糖脂質抗体}

膜糖脂質は腫瘍関連抗原である。多くの糖脂質が正常組 織と比較して腫瘍では、発現が過剩になる変化がある。腫瘍 糖脂質を認識する抗体は、補体を強く活性化し抗体に依存し た細胞性障害を仲介している。そのため、糖脂質マーカーは ヒトがんの診断および治療のための有用な標的になりうる $(10)$ 。

糖脂質の潜在性は、がんの免疫療法の標的として追跡す る際におこるむずかしい問題である。以前マウスに同系のメ ラノーマB16細胞を免疫することで、ガングリオシド GM3 を認識するモノクローナル抗体M2590が樹立された。この M2590 抗体の反応性はB16細胞表面における GM3 の密度に 依存している $(11)$ 。密度に、抗体がすべて認識するか全く認 識しないかの闇值が存在する。M2590抗体の反応性はヒト グリオーマKG-1Cの細胞密度にも依存している (12)。潜在 GM3 は確かに細胞表面に存在し、その潜在性は可逆的であ る。GM3 はKG-1Cグリオーマ細胞に発現している唯一の糖 脂質であることから、当然他の糖脂質による立体障害ではな い。生きた神経細胞膜のガングリオシド GM1 は抗 GM1 モノ クローナル抗体DG1 と結合するが、抗体結合にかかわる頭 部の糖鎖領域がガングリオシドGD1a との相互作用で隠され ることにより結合しなくなる $(13)$ 。糖脂質の潜在性の正確な 
precise mechanism underlying glycolipid crypticity remains to be explored. Detergent-resistant membrane rafts act as an effective immunogen. Raft immunization was used to produce monoclonal antibodies against glycolipids $(14,15)$.

\section{Heterogeneity in Lipid Rafts}

Lipid rafts are spatially heterogeneous in a single cell membrane. In a migrating T cell, ganglioside GM3-rich rafts containing a chemokine receptor CXCR4 and Rho localize to the cell front (leading edge), whereas GM1-rich rafts containing integrin $\beta 1$ and CD44 localize to the cell rear (uropod) (16). Sphingomyelinrich rafts are spatially distinct from ganglioside GM1-rich rafts in Jurkat T cells (17) Gangliosides GM3 and GM1 are present in distinct microdomains in the apical domain of epithelial cells. Freeze-fracture immunolabeling electron microscopy showed that ganglioside GM3 and GM1 make independent clusters of $<100 \mathrm{~nm}$ in diameter in fibroblasts (18). Sphingomyelin-rich rafts localize in the central region of adhering platelets with thrombin, whereas cholesterol-rich rafts localize evenly on the membrane. Sphingomyelin-rich rafts act as platforms of fibrin-mediated outside-in signals, leading to clot retraction (19). These observations suggest that lipid rafts are compositionally and functionally heterogeneous (20).

\section{Heterogeneity in Raft Signaling}

Cholera toxin B subunits are able to bind as a pentamer to ganglioside GM1. Ligation of GM1 by cholera toxin B subunits induces tyrosine phosphorylation of LAT, $\mathrm{Ca}^{2+}$ flux and MAP kinase activation in Jurkat T cells (Fig. 1) (21). Ligation of Gb3 by
機構はまだわかっていない。

界面活性剂耐性ラフト膜は効果的な抗原になることが知 られている。ラフトを免疫することで、糖脂質に対するモノ クローナル抗体が得られている $(14,15)$ 。

\section{C. 脂質ラフトの不均一性}

脂質ラフトは一つの細胞の膜の中で、空間的に不均一で ある。移動している T細胞の前方（先端）にケモカイン受容 体 CXCR4 とRhoを含むガングリオシド GM3 に富むラフトが 局在し、細胞後方 (尾肢) にインテグリン $\beta 1$ と CD44を含む GM1 に富むラフトが局在する $(16)$ 。スフィンゴミエリンに 富むラフトはJurkat T細胞においてガングリオシド GM1 に富 むラフトと空間的に区別される (17)。ガングリオシド GM3 と GM1 は、上皮細胞のアピカル領域において異なるミクロ ドメインに存在する。フリーズフラクチャー免疫標識電子顕 微鏡法によりガングリオシド GM3 と GM1 は、線維芽細胞に おいて直径 $100 \mathrm{~nm}$ 以下の独立したクラスターを形成してい ることが示された (18)。トロンビン刺激で接着させた血小板 においてスフィンゴミエリンに富むラフトは中央領域に局在 するのに対し、コレステロールに富むラフトは全体に存在し た。スフィンゴミエリンに富むラフトは、フィブリンが媒介 する Outside-in signalの中継点として働き、血餅退縮を引き 起こす(19)。これらのことは、脂質ラフトは構成的および機 能的に不均一であること示している $(20)$ 。

\section{D. ラフトシグナルの不均一性}

コレラ毒素 Bサブユニットは 5 量体でガングリオシド GM1 に結合する。Jurkat T細胞においてコレラ毒素Bサブユ ニットがGM1に結合すると、LATチロシンリン酸化、カル シウム動員、MAPキナーゼ活性化が引き起こされる（Fig. 1）

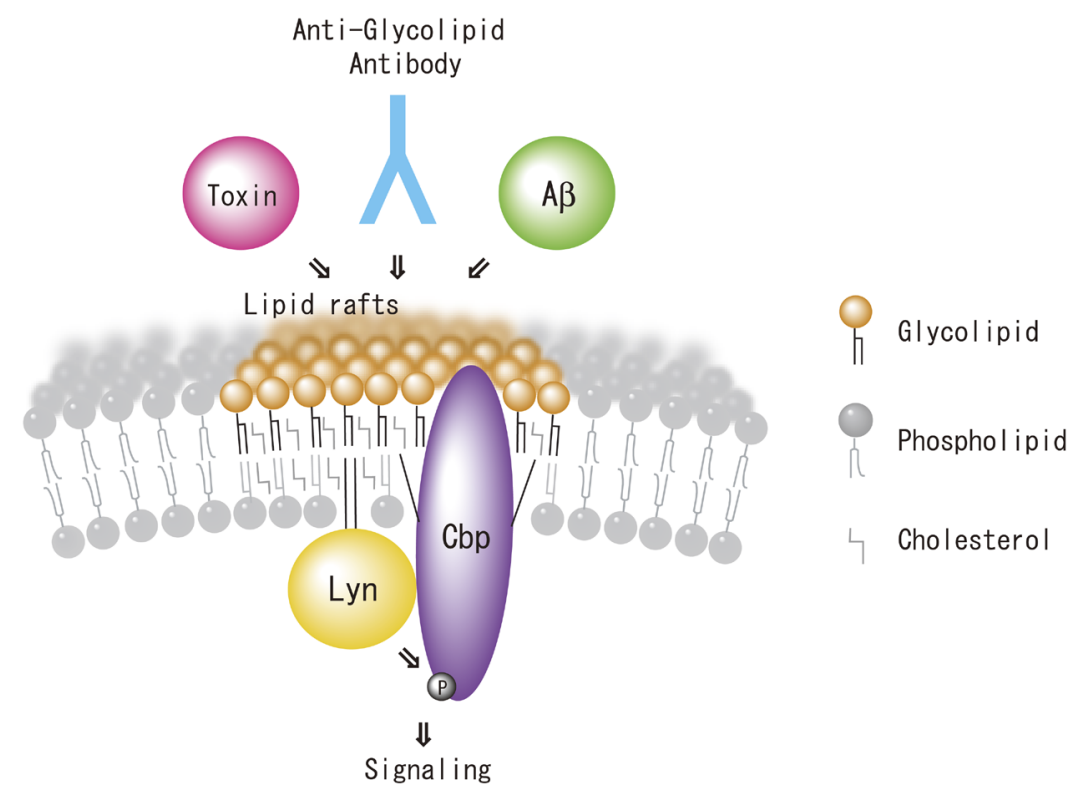

Fig. 1. Signal transduction by anti-glycolipid antibody, bacterial toxin and amyloid $\beta$ protein in lipid rafts. Ligation of glycolipids with anti-glycolipid antibody, bacterial toxin (Toxin) and amyloid $\beta$ protein $(\mathrm{A} \beta$ ) could induce transmembrane signaling in lipid rafts. 
Shiga toxin B subunits induces activation of src-family kinase Yes in Burkitt's lymphoma (22). Lysenin, an earthworm toxin, specifically binds to sphingomyelin-rich rafts and induces clustering of sphingomyelin-rich rafts and tyrosine phosphorylation of Cbl (23). These observations show the heterogeneity of raft signaling (24).

Two raft subfractions of melanoma B16 cells were separated by immunoprecipitation using an anti-ganglioside GM3 monoclonal antibody (25), suggesting that anti-glycosphingolipid monoclonal antibodies are tools for analysis of specific lipid rafts. The antiganglioside GM3 monoclonal antibody DH2 immunoprecipitates
(21)。バーキットリンパ腫細胞において志賀毒素Bサブユ ニットが Gb3に結合すると、srcファミリーキナーゼ Yesが活 性化する (22)。ミミズ毒素のライセニンはスフィンゴミエリ ンに富むラフト特異的に結合し、スフィンゴミエリンに富む ラフトのクラスター化、 $\mathrm{Cbl}$ のチロシンリン酸化を引き起こ す $(23)$ 。これらのことは、ラフトシグナルが不均一であるこ とを示している $(24)$ 。

抗ガングリオシドGM3モノクローナル抗体を使った免 疫沈降によって、メラノーマB16細胞のラフトを二つの画分 に分けることができる(25)。これは抗スフィンゴ糖脂質モノ クローナル抗体が脂質ラフトの特異性を解析する道具であ

Table 1. Anti-glycolipid monoclonal antibodies co-immunoprecipitate signaling molecules.

\begin{tabular}{|c|c|c|c|c|}
\hline Antibody & Clone & Signaling molecule & Reference & \\
\hline LacCer & Huly-m13 & Lyn & Iwabuchi et al. & Blood 100, 1454-1464 (2002) \\
\hline GM3 & $\mathrm{DH} 2$ & c-src & Iwabuchi et al. & J. Biol. Chem. 273, 9130-9138 (1998) \\
\hline GM3 & $\mathrm{DH} 2$ & FAK & Iwabuchi et al. & J. Biol. Chem. 273, 9130-9138 (1998) \\
\hline GM3 & $\mathrm{DH} 2$ & Rho & Iwabuchi et al. & J. Biol. Chem. 273, 9130-9138 (1998) \\
\hline GM3 & $\mathrm{DH} 2$ & CXCR4 & Sorice et al. & FEBS Lett. 506, 55-60 (2001) \\
\hline GD3 & $\mathrm{R} 24$ & Lyn & Kasahara et al. & J. Biol. Chem. 272, 29947-29953 (1997) \\
\hline GD3 & $\mathrm{R} 24$ & Cbp & Sekino-Suzuki et al. & J. Neurochem. 124, 514-522 (2013) \\
\hline GD3 & $\mathrm{R} 24$ & Go $\alpha$ & Yuyama et al. & J. Biol. Chem. 282, 26392-26400 (2007) \\
\hline GD3 & $\mathrm{R} 24$ & EGF receptor & Wang et al. & Proc. Natl. Acad. Sci. U.S.A. 110. 19137-19142 (2013) \\
\hline 9-O-Acetyl GD3 & $27 \mathrm{~A}$ & caveolin-1 & Simons et al. & Am. J. Pathol. 159,1069-1077 (2001) \\
\hline Fuc(Gal)-GM1 & $\mathrm{PR} \# 1$ & Fyn, Yes & Yamazaki et al. & Biochem. J. 407, 31-40 (2007) \\
\hline$\alpha \mathrm{GalGD} 1 \mathrm{~b}$ & AA4 & Lyn & Minoguchi et al. & J. Biol. Chem. 269, 5249-5254 (1994) \\
\hline Gb3 & 38.13 & Yes & Katagiri et al. & J. Biol. Chem. 274, 35278-35282 (1999) \\
\hline DSGG & RM2 & c-src & Satoh et al. & Int. J. Oncol. 16, 529-536 (2000) \\
\hline DSGG & RM2 & Rho & Satoh et al. & Int. J. Oncol. 16, 529-536 (2000) \\
\hline Sulfatide & $\mathrm{O} 4$ & Fyn, Lyn & Miki et al. & Glycoconj. J. 30, 819-823 (2013) \\
\hline PtdGlc & rGL-7 & Lyn, Hck, Cbp & Nagatsuka et al. & Proc. Natl. Acad. Sci. U.S.A. 100, 7454-7459 (2003) \\
\hline
\end{tabular}

Table 2. Cellular response by anti-glycolipid antibodies.

\begin{tabular}{|c|c|c|c|}
\hline Antibody & Cell & Response & Reference \\
\hline GalCer & Oligodendrocytes & $\mathrm{Ca}^{2+}$ flux & J. Cell. Biol. 111, 625-633 (1990) \\
\hline LacCer & Neutrophils & Lyn, p38 MAPK activation & Blood 100, 1454-1464 (2002) \\
\hline GM3 & Melanoma B16 & FAK phosphorylation & J. Biol. Chem. 273, 9130-9138 (1998) \\
\hline GD3 & Cerebellar granule cells & Lyn, p42/44 MAPK activation & J. Biol. Chem. 272, 29947-29953 (1997) \\
\hline 9-O-Acetyl GD3 & Blood mononuclear cells & PI turnover & Scand. J. Immunol. 48, 615-622 (1998) \\
\hline GD2 & IMR-32 neuroblastoma & Apoptosis & Cancer Lett. 281, 171-182 (2009) \\
\hline$O$-Acetyl GD2 & Tumor cell line & Apoptosis & Cancer Lett. 333, 194-204 (2013) \\
\hline Asialo-GM1 & Muscle-spinal cocultured cells & Voltage-gated $\mathrm{Ca}^{2+}$ channel inhibition & Neurochem. Res. 29, 953-960 (2004) \\
\hline GD1a & Postnatal cerebellar neurons & RhoA activation & J. Neurochem. 94, 15-21 (2005) \\
\hline GalNAc-GD1a & PC12 pheochromocytoma cells & Voltage-gated $\mathrm{Ca}^{2+}$ channel inhibition & Exp. Neurol. 204, 380-386 (2007) \\
\hline GD1a/GT1b & Primary neuronal cultures & RhoA, ROCK activation & J. Neurosci. 31, 1664-1675 (2011) \\
\hline GD1b & Cerebellar granule cells & Protein tyrosine phosphorylation & J. Neurochem. 124, 514-522 (2013) \\
\hline$\alpha$ GalGD1b & Basophilic leukemia RBL-2H3 & Lyn, Syk Activation & J. Biol. Chem. 269, 19466-19473 (1994) \\
\hline GT1b & Keratinocyte-derived SCC12 & Ser473-Akt phosphorylation & J. Biol. Chem. 276, 44504-44511 (2001) \\
\hline GT1b & Postnatal cerebellar neurons & Association of p75NTR to lipid rafts & J. Neurochem. 94, 15-21 (2005) \\
\hline PtdGlc & Neural progenitor cells & EGF receptor activation & Biochem. J. 419, 565-575 (2009) \\
\hline
\end{tabular}


GM3-rich rafts containing c-Src (Table 1). Treatment with DH2 induces the phosphorylation of c-Src and FAK in melanoma B16 cells (Fig. 1, Table 2). The anti-lactosylceramide (LacCer) monoclonal antibody Huly-m13 immunoprecipitates LacCer-rich rafts containing src-family kinase Lyn of human neutrophils. Treatment of neutrophils with the anti-LacCer monoclonal antibody T5A7 induces activation of Lyn, p38MAP kinase and superoxide generation (26). Treatment of keratinocyte-derived SCC12 cells with the anti-ganglioside GT1b antibody, but not with an anti-ganglioside GD3 antibody, induces the phosphorylation of Ser-473 of Akt (27). Treatment of peripheral blood mononuclear cells with the anti9-O-acetyl GD3 monoclonal antibody 27A, but not with the antiGD3 antibody, induces tyrosine phosphorylation of p72syk despite the similar cell surface distribution of the two gangliosides (28). Treatment of neural progenitor cells with the anti-PtdGlc monoclonal antibody DIM21 induces recruitment of EGF receptors into lipid rafts, leading to the activation of EGF receptors (29). Furthermore, the anti-ganglioside GD3 monoclonal antibody R24 immunoprecipitates GD3-rich rafts containing Lyn and its substrate Cbp of rat cerebellar granule cells $(30,31)$. Treatment with R24 induces Lyn activation, phosphorylation of Cbp and p42/44 MAP kinase, and filamentous actin assembly in cerebellar granule cells (32). In a model of Lyn activation by crosslinking of ganglioside GD3 with R24, it is assumed that GD3 crosslinking leads to coalescence of lipid rafts. This may induce clustering of Lyn and transphosphorylation of tyrosine residue in the kinase domain (activating site, Tyr 397; homologous to c-Src Tyr 416) (24).

However, it should be noted that anti-glycosphingolipid monoclonal antibody treatment represents artificial stimulation. Previously, we attempted to identify the cell-surface molecules involved in Lyn signaling, because Lyn is a nonreceptor-type kinase. R24 co-immunoprecipitates the GPI-anchored neural cell adhesion molecule TAG-1, and the antibody-mediated crosslinking of TAG1 induces Lyn activation in cerebellar granule cells $(33,34)$. Our previous study demonstrated that GPI-anchored TAG-1 transduces intracellular signaling via Lyn in GD3-rich rafts of cerebellar granule cells. Therefore, anti-glycosphingolipid monoclonal antibodies are useful tools for the analysis of heterogeneity in raft signaling.

\section{E. Autoimmune Neuropathy and Anti-Glycolipid An- tibodies}

Guillain-Barré and Fisher syndromes, characterized by peripheral neuropathy with the clinical symptom of peripheral nerve dysfunction, are postinfectious autoimmune diseases. Campylobacter jejuni is the most frequent causal pathogen. The affected patients have anti-ganglioside antibodies, because lipopolysaccharides of Campylobacter jejuni have ganglioside-like epitopes
ることを示している。抗ガングリオシドGM3モノクローナ ル抗体DH2 は、c-Srcを含むガングリオシド GM3に富むラフ 卜を免疫沈降する（Table 1)。メラノーマB16細胞をDH2で 処理すると c-Src, FAKのリン酸化が起こる（Fig. 1, Table 2）。 抗ラクトシルセラミド (LacCer) モノクローナル抗体Hulym13 は、ヒト好中球から src ファミリーキナーゼLynを含む LacCerに富むラフトを免疫沈降する。好中球を抗LacCerモ ノクローナル抗体 T5A7で処理すると、Lyn, p38MAPキナー ゼの活性化、活性酸素の産生が起こる(26)。ケラチノサイ 卜由来 SCC12細胞を抗ガングリオシド GT1b抗体で処理する と、Aktの 473 番目のセリンのリン酸化が起こるが、抗ガン グリオシドGD3 抗体では起こらない(27)。末梢血単核細胞 を抗9-O-acetyl GD3 抗体で処理すると、p72Sykのリン酸化 が起こるが、細胞に同程度二つのガングリオシドが発現し ているにもかかわらず抗ガングリオシドGD3抗体では起こ らない(28)。神経前駆細胞を抗PtdGlcモノクローナル抗体 DIM21で処理すると、EGF受容体が脂質ラフトに移行し活 性化する(29)。さらに、抗ガングリオシドGD3モノクロー ナル抗体R24 は、ラット小脳顆粒細胞から Lyn とその基質で あるCbpを含むガングリオシドGD3に富むラフトを免疫沈 降する $(30,31)$ 。小脳顆粒細胞をR24で処理すると、Lynの 活性化、Cbp, p42/p44MAPのリン酸化、F-actinの重合が起こ る(32)。R24によるガングリオシドGD3クロスリンクによる Lyn 活性化のモデルとして、GD3クロスリンクによる脂質 フトの合体が考えられている。このことがLynのクラスター 化、キナーゼ領域の活性化部位（397番目のチロシン、cSrc416番目のチロシンに相同）のトランスリン酸化（互いに 相手をリン酸化）を起すかもしれない(24)。

しかし、抗スフィンゴ糖脂質モノクローナル抗体処理 というのは人工的な刺激であることに注意しなければなら ない。以前我々は、Lynは非受容体型キナーゼであることか ら、Lyn シグナルにかかわる細胞表面分子の同定を試みた。 R24 は小脳顆粒細胞において GPIアンカー神経細胞接着分子 TAG-1 を共沈し、TAG-1 を抗体でクロスリンクすると Lynが 活性化する $(33,34)$ 。この研究は、GPIアンカーTAG-1 が小 脳顆粒細胞においてガングリオシドGD3に富むラフトに局 在するLynを介して細胞内にシグナルを伝達していることを 示している。よって抗スフィンゴ糖脂質モノクローナル抗体 は、ラフトシグナルの不均一性を解析するための有用な道具 である。

\section{E. 自己免疫性神経疾患と抗糖脂質抗体}

ギランバレー症候群やフィッシャー症候群は、末梢神 経障害を臨床症状とする感染後自己免疫性神経疾患である。 最も感染頻度の高い病原体はCampylobacter jejuniである。 Campylobacter jejuniのリポポリサッカライドはガングリオシ ド様のエピトープを持っているため、患者は抗ガングリオシ ド抗体を持っている $(35)$ 。ギランバレー症候群患者の急性期 
(35). IgG antibodies against ganglioside GM1, GD1a and GalNAcGD1a are present in the acute phase sera from patients with Guillain-Barré syndrome. Anti-ganglioside IgG antibodies bind to the ganglioside antigen that is localized in the nodes of Ranvier of peripheral nerves causing muscle weakness. IgG antibodies against ganglioside GQ1b are present in the acute phase sera from patients with Fisher syndrome. Anti-GQ1b IgG antibodies bind to the GQ1b antigen that is localized in the paranodal myelin of the cranial nerves innervating ocular muscles causing ophthalmoplegia. Anti-ganglioside antibodies are thought to activate complements, causing axonal damage and thereby disturbing action potential conduction. However, complement-independent nerve dysfunction has been suggested by in vitro studies showing that anti-ganglioside antibodies directly change the integrity of lipid rafts. This is consistent with the finding that the patient's anti-GM1 antibody alters the distribution of Trk in lipid rafts (36). Patient's anti-GD1a/ GT1b antibody activates RhoA and ROCK, and inhibits neurite outgrowth (37). Lipid raft function might be impaired by the patient's anti-ganglioside antibodies. The discovery of anti-glycolipid antibodies that bind to heteromeric glycolipid complexes provides a new concept in antibody-antigen interactions through clustered carbohydrate epitopes (38). Anti-GM1/GD1a, GD1a/GD1b, GD1b/ GT1b complex antibodies are associated with Guillain-Barré syndrome (39), whereas anti-GM1/GQ1b, GD1a/GQ1b complex antibodies are associated with Fisher syndrome (40). Anti-ganglioside complex antibodies might induce heterogenous coalescence of lipid rafts.

\section{F. Alzheimer's Disease and Gangliosides}

Neuronal degeneration is due to the formation of senile plaques in Alzheimer's disease. The amyloid $\beta$ protein, the main component of senile plaques, localizes in lipid rafts by its direct binding to ganglioside GM1 clusters (41). The N-terminal region of the amyloid $\beta$ protein binds to ganglioside GM1 through hydrogen bonding and electrostatic interactions (42) on neuronal membranes, leading to the formation of an endogenous seed with an altered conformation (ganglioside-bound amyloid $\beta$ ) for amyloid fibril formation in the brain. Notably, the risk factors for the development of Alzheimer's disease, including aging and expression of apolipoprotein E4, likely facilitate the formation of lipid raft microdomains at presynaptic terminals, which provide a favorable milieu for the ganglioside-bound amyloid $\beta$ generation.

This amyloid $\beta$ protein binding to gangliosides might perturb physiological raft signaling in neurons, because the binding of cholera toxin B subunits or Shiga toxin B subunits to glycosphingolipids on intact cells induce signal transduction via lipid rafts (Fig. 1). Amyloid $\beta$ protein binding to ganglioside GM1 induces
血清にはガングリオシドGM1, GD1a と GalNAc-GD1aに対す る IgG抗体が存在する。抗ガングリオシド $\operatorname{IgG}$ 抗体は末梢神 経ランビエ絞輪に局在するガングリオシド抗原に結合し、筋 力低下を引き起こす。フィッシャー症候群患者の急性期血清 にはガングリオシド GQ1bに対するIgG抗体が存在する。抗 ガングリオシド GQ1b IgG抗体は顔筋を支配する脳神経の傍 絞輪部ミエリンに局在する GQ1b抗原に結合し、眼筋麻痺を 引き起こす。抗ガングリオシド抗体は補体を活性化し、軸索 損傷を引き起こし活動電位の伝達を妨げると考えられてい る。しかし、抗ガングリオシド抗体が直接脂質ラフトを不完 全な状態にするという in vitroの研究があり、補体に依存し ない神経障害も提案されている。この考えは、患者 GM1 抗 体が脂質ラフトにおける Trkの分布を変化させる報告と一致 する(36)。患者GD1a/GT1b抗体がRhoA, ROCKを活性化し、 神経突起伸長を阻害する (37)。脂質ラフトの機能が患者の抗 ガングリオシド抗体によって障害されるのかもしれない。

異なる糖脂質複合体に結合する抗体が発見され、糖鎖 クラスターエピトープを介した抗体抗原相互作用という新 しい概念が生まれた (38)。抗 GM1/GD1a, GD1a/GD1b, GD1b/ $\mathrm{GT} 1 \mathrm{~b}$ 複合体抗体はギランバレー症候群と関連している (39)。 抗 GM1/GQ1b, GD1a/GQ1b 複合体抗体はフィッシャー症候群 と関連している $(40)$ 。抗ガングリオシド複合体抗体は、異な る脂質ラフトの合体を引き起こすかもしれない。

\section{F. アルツハイマー病とガングリオシド}

アルツハイマー病における神経変性は老人斑の形成に よっている。アミロイド $\beta$ タンパク質は老人斑の主な構成成 分であり、ガングリオシド GM1クラスターに直接結合する ことにより脂質ラフトに存在する $(41)$ 。アミロイド $\beta$ タンパ ク質の $\mathrm{N}$ 末領域が水素結合と静電相互作用により神経細胞 膜のガングリオシド GM1に結合し(42)、脳内においてコン フォーメーションを変え（ガングリオシド結合型アミロイ ド $\beta$ タンパク質）アミロイド線維形成を起す内在性の「種」 になる。興味深いことに、アルツハイマー病発症の危険因子 である脳老化やアポリポタンパク質E4の発現は、神経突起 末端においてガングリオシド結合型アミロイド $\beta$ タンパク質 形成に適した環境である脂質ラフトの形成を誘導する。

無傷細胞の糖脂質にコレラ毒素Bサブユニットや志賀毒 素 $\mathrm{B}$ サブユニットが結合すると脂質ラフトにおけるシグナル 伝達が惹起されることから、アミロイド $\beta$ タンパク質がガン グリオシドに結合すると神経細胞における生理的なラフトシ グナルを妨げるかもしれない（Fig. 1)。アミロイド $\beta$ タンパ ク質がガングリオシド GM 1 に結合すると、アミロイド $\beta$ タン 
the recruitment of the amyloid $\beta$ protein into lipid rafts by srcfamily kinase Fyn-dependent mechanisms (43), decrease GM1 lateral diffusion (44), enhancement of phase separation during amyloid $\beta$ protein aggregation (45), accumulation of apolipoprotein $\mathrm{E}$ and phosphorylated tau in lipid rafts (46), lipid oxidation, $\mathrm{Ca}^{2+}$ dyshomeostasis, membrane permeabilization (47) in intact cells, and changes in dynamics of the raft-model membrane (48). Furthermore, lipid raft disruption protects mature neurons against amyloid $\beta$ oligomer toxicity (49).
パク質は srcファミリーキナーゼFynに依存して機構によっ て脂質ラフトに移行し(43)、GM1の側方拡散が減少し(44)、 アミロイド $\beta$ タンパク質の凝集に伴い相分離が増加し(45)、 脂質ラフトにアポリポタンパク質 $\mathrm{E}$ およびリン酸化 tauが蓄 積し (46)、脂質酸化、カルシウム恒常性不全、膜透過が無傷 細胞で起こり (47)、ラフトモデル膜においては動的変化が起 こる $(48)$ 。さらに脂質ラフトを破壊すると、アミロイド $\beta$ タ ンパク質オリゴマーの成熟神経細胞に対する毒性から保護さ れる $(49) 。$

\section{References}

1. Simons, K., and Gerl, M. J. (2010) Nat. Rev. Mol. Cell Biol. 11, 688-699.

2. Prinetti, A., Chigorno, V., Prioni, S., Loberto, N., Marano, N., Tettamanti, G., and Sonnino, S. (2001) J. Biol. Chem. $276,21136-21145$.

3. Nagatsuka, Y., Hara-Yokoyama, M., Kasama, T., Takekoshi, M., Maeda, F., Ihara, S., Fujiwara, S., Ohshima, E., Ishii, K., Kobayashi, T., Shimizu, K., and Hirabayashi, Y. (2003) Proc. Natl. Acad. Sci. U.S.A. 100, 7454-7459.

4. Hrdinka, M., and Horejsi, V. (2013) Oncogene advance online publication, doi:10.1038/onc.2013.485

5. Wange, R. L. (2000) Sci. STKE 2000, re1.

6. Viola, A., Schroeder, S., Sakakibara, Y., and Lanzavecchia, A. (1999) Science 283, 680-682.

7. Mishra, R., Grzybek, M., Niki, T., Hirashima, M., and Simons, K. (2010) Proc. Natl. Acad. Sci. U.S.A. 107, 17633-17638.

8. Delacour, D., Gouyer, V., Zanetta, J. P., Drobecq, H., Leteurtre, E., Grard, G., Moreau-Hannedouche, O., Maes, E., Pons, A., André, S., Le Bivic, A., Gabius, H. J., Manninen, A., Simons, K., and Huet, G. (2005) J. Cell Biol. 169, 491-501.

9. Suzuki, K. G. (2012) Biotechnol. J. 7, 753-761.

10. Hakomori, S. (1983) Bull. Cancer 70, 118-126.

11. Nores, G. A., Dohi, T., Taniguchi, M., and Hakomori, S. (1987) J. Immunol. 139, 3171-3176.

12. Tatewaki, K., Yamaki, T., Maeda, Y., Tobioka, H., Piao, H., Yu, H., Ibayashi, Y., Sawada, N., and Hashi, K. (1997) Exp. Cell Res. 233, 145-154.

13. Greenshields, K. N., Halstead, S. K., Zitman, F. M., Rinaldi, S., Brennan, K. M., O’Leary, C., Chamberlain, L. H., Easton, A., Roxburgh, J., Pediani, J., Furukawa, K., Goodyear, C. S., Plomp, J. J., and Willison, H. J. (2009) J. Clin. Invest. 119, 595-610.

14. Katagiri, Y. U., Nakajima, H., Sato, B., Miyagawa, Y., Horiuchi, Y., Okita, H., Fujimoto, J., and Kiyokawa, N. (2008) Glycoconj. J. 25, 495-501.

15. Hirabayashi, Y. (2012) Proc. Jpn. Acad., Ser. B, Phys. Biol. Sci. 88, 129-143.

16. Gómez-Móuton, C., Abad, J. L., Mira, E., Lacalle, R. A., Gallardo, E., Jiménez-Baranda, S., Illa, I., Bernad, A., Mañes, S., and Martínez-A, C. (2001) Proc. Natl. Acad. Sci. U.S.A. 98, 9642-9647.

17. Kiyokawa, E., Baba, T., Otsuka, N., Makino, A., Ohno, S., and Kobayashi, T. (2005) J. Biol. Chem. $280,24072-24084$.

18. Fujita, A., Cheng, J., Hirakawa, M., Furukawa, K., Kusunoki, S., and Fujimoto, T. (2007) Mol. Biol. Cell 18, $2112-2122$.

19. Kasahara, K., Kaneda, M., Miki, T., Iida, K., Sekino-Suzuki, N., Kawashima, I., Suzuki, H., Shimonaka, M., Arai, M., Ohno-Iwashita, Y., Kojima, S., Abe, M., Kobayashi, T., Okazaki, T., Souri, M., Ichinose, A., and Yamamoto, N. (2013) Blood 122, 3340-3348.

20. Hakomori Si, S. I. (2002) Proc. Natl. Acad. Sci. U.S.A. 99, 225-232.

21. Janes, P. W., Ley, S. C., and Magee, A. I. (1999) J. Cell Biol. 147, 447-461.

22. Katagiri, Y. U., Mori, T., Nakajima, H., Katagiri, C., Taguchi, T., Takeda, T., Kiyokawa, N., and Fujimoto, J. (1999) J. Biol. Chem. 274, 3527835282.

23. Kulma, M., Kwiatkowska, K., and Sobota, A. (2012) Cell. Signal. 24, 1641-1647.

24. Kasahara, K., and Sanai, Y. (2000) Glycoconj. J. 17, 153-162.

25. Iwabuchi, K., Handa, K., and Hakomori, S. (1998) J. Biol. Chem. 273, 33766-33773.

26. Iwabuchi, K., and Nagaoka, I. (2002) Blood 100, 1454-1464.

27. Wang, X. Q., Sun, P., and Paller, A. S. (2001) J. Biol. Chem. 276, 44504-44511.

28. Reivinen, J., Holthöfer, H., and Miettinen, A. (1998) Scand. J. Immunol. 48, 615-622.

29. Kinoshita, M. O., Furuya, S., Ito, S., Shinoda, Y., Yamazaki, Y., Greimel, P., Ito, Y., Hashikawa, T., Machida, T., Nagatsuka, Y., and Hirabayashi, Y. (2009) Biochem. J. 419, 565-575.

30. Kasahara, K., Watanabe, Y., Yamamoto, T., and Sanai, Y. (1997) J. Biol. Chem. 272, $29947-29953$.

31. Sekino-Suzuki, N., Yuyama, K., Miki, T., Kaneda, M., Suzuki, H., Yamamoto, N., Yamamoto, T., Oneyama, C., Okada, M., and Kasahara, K. (2013) J. Neurochem. 124, 514-522.

32. Yuyama, K., Sekino-Suzuki, N., Yamamoto, N., and Kasahara, K. (2011) J. Neurochem. 116, $845-850$.

33. Kasahara, K., Watanabe, K., Takeuchi, K., Kaneko, H., Oohira, A., Yamamoto, T., and Sanai, Y. (2000) J. Biol. Chem. $275,34701-34709$.

34. Prinetti, A., Prioni, S., Chigorno, V., Karagogeos, D., Tettamanti, G., and Sonnino, S. (2001) J. Neurochem. 78, $1162-1167$.

35. Kuwabara, S., and Yuki, N. (2013) Lancet Neurol. 12, 1180-1188.

36. Ueda, A., Shima, S., Miyashita, T., Ito, S., Ueda, M., Kusunoki, S., Asakura, K., and Mutoh, T. (2010) Mol. Cell. Neurosci. 45, 355-362.

37. Zhang, G., Lehmann, H. C., Manoharan, S., Hashmi, M., Shim, S., Ming, G. L., Schnaar, R. L., Lopez, P. H., Bogdanova, N., and Sheikh, K. A. (2011) J. Neurosci. 31, 1664-1675.

38. Willison, H. J., and Goodyear, C. S. (2013) Trends Immunol. 34, 453-459.

39. Kaida, K., Morita, D., Kanzaki, M., Kamakura, K., Motoyoshi, K., Hirakawa, M., and Kusunoki, S. (2004) Ann. Neurol. 56, 567-571. 
40. Kaida, K., Kanzaki, M., Morita, D., Kamakura, K., Motoyoshi, K., Hirakawa, M., and Kusunoki, S. (2006) J. Neurol. Neurosurg. Psychiatry 77, 1043-1046.

41. Yanagisawa, K. (2011) J. Neurochem. 116, 806-812.

42. Lemkul, J. A., and Bevan, D. R. (2011) Protein Sci. 20, 1530-1545.

43. Williamson, R., Usardi, A., Hanger, D. P., and Anderton, B. H. (2008) FASEB J. 22, 1552-1559.

44. Sasahara, K., Morigaki, K., and Shinya, K. (2013) Phys. Chem. Phys. 15, 8929-8939.

45. Calamai, M., and Pavone, F. S. (2013) FEBS Lett. 587, 1385-1391.

46. Kawarabayashi, T., Shoji, M., Younkin, L. H., Wen-Lang, L., Dickson, D. W., Murakami, T., Matsubara, E., Abe, K., Ashe, K. H., and Younkin, S. G. (2004) J. Neurosci. 24, 3801-3809.

47. Evangelisti, E., Wright, D., Zampagni, M., Cascella, R., Fiorillo, C., Bagnoli, S., Relini, A., Nichino, D., Scartabelli, T., Nacmias, B., Sorbi, S., and Cecchi, C. (2013) Curr. Alzheimer Res. 10, 143-153.

48. Hirai, M., Kimura, R., Takeuchi, K., Sugiyama, M., Kasahara, K., Ohta, N., Farago, B., Stadler, A., and Zaccai, G. (2013) Soft Matter 36, 74.

49. Malchiodi-Albedi, F., Contrusciere, V., Raggi, C., Fecchi, K., Rainaldi, G., Paradisi, S., Matteucci, A., Santini, M. T., Sargiacomo, M., Frank, C., Gaudiano, M. C., and Diociaiuti, M. (2010) Biochim. Biophys. Acta 1802, 406-415.

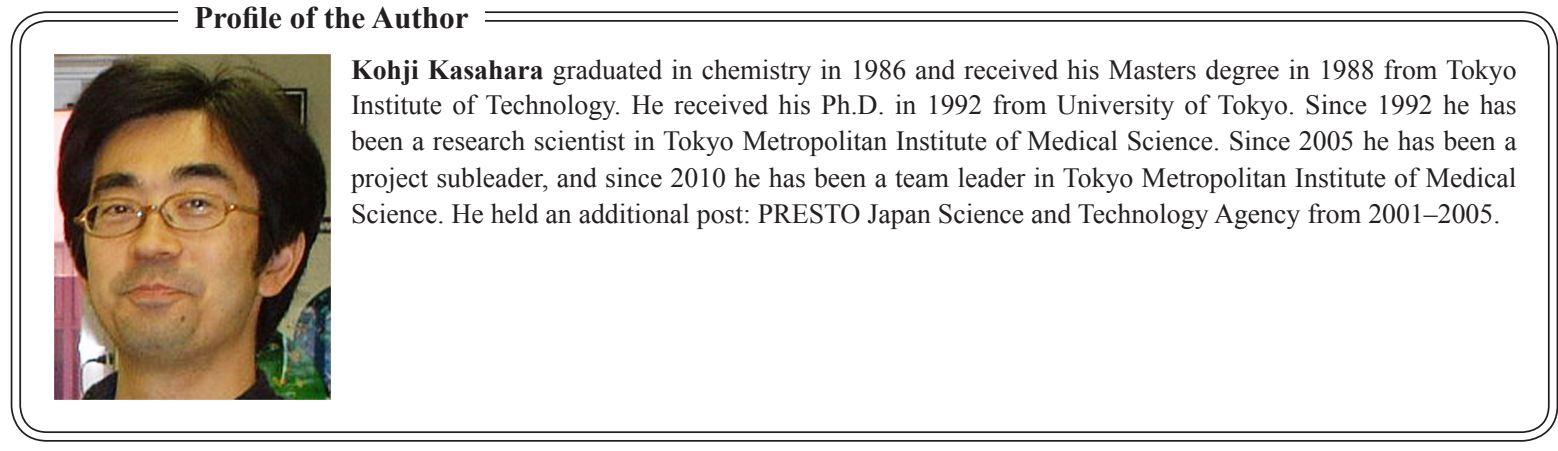

